\title{
Labor Contracts and Shirking in Cameroon
}

\author{
Roger A. Tsafack Nanfosso \\ The University of Yaoundé II-Soa, Faculty of Economics and Management \\ Tel: (237)-77-580-278 E-mail: rtsafack@hotmail.com \\ Benjamin Fomba Kamga \\ The University of Yaoundé II-Soa, Faculty of Economics and Management \\ Tel: (237)-77-320-835 E-mail: fomba1@yahoo.fr
}

\begin{abstract}
This paper evaluates and analyzes the effects of labor contracts on shirking in Cameroonian firms. This study uses the survey data collected in 2006 in Cameroonian manufacturing firms having more than 15 employees. Data processing produced a sample of 65 companies and 1809 employees. In addition to permanent or temporary distinctions, we considered the verbal aspect of labor contracts, affiliation to social security and promotion within the labor market. Econometric estimations take into account the endogeneity of the contractual trajectory of employees. Results are estimated in 2 stages. First, we evaluate the determinants of contract choice and the second; we estimate the degree in Cameroonian firms. This degree is measured by the level of effort deployed by workers. Results show that permanent employees after a verbal contract work harder than those who are permanent since their recruitment. In addition, the employees under short term contracts since their recruitment are more inclined to shirk as well as those who are permanent since their recruitment. Employees without social security are likely to cheat than those with social security and recruited permanently since the beginning.
\end{abstract}

Keywords: Labor contracts, Cameroon, Shirking, Logistic regression.

\section{Introduction}

Since the end of the 1980s, one of the most important characteristics of labor contracts is its duration, which can be specified or unspecified. The increase in the number of employees under a specified period contract has been subjected to many scientific works (Booth et al., 2002). However, the questions often treated by the researchers are relative on one hand to the macroeconomic impact of temporary contracts on unemployment and job creation (Cahuc and Postel-Vinay, 2002; and Blanchard and Landier, 2002) and on the other hand, the microeconomic effects of part-time employment on the output of the labor market such as wages, on-the-job training, or the transition from temporary contract to permanent contract (D' Addio and Rosholm, 2005; Güell and Petrongolo, 2007).

Papers which focus on the incentive behavior of temporary contracts in the Africa are rare. But elsewhere, by considering part-time jobs as a stepping stone towards a permanent employment, employees under temporary contracts are more willing to make efforts than those under permanent contracts (Engellandt and Riphahn in 2005), and this lecvel of effort falls when they are promoted to permanent contracts (Ichino and Riphanh, 2001; Booth et al., 2002). On the other hand, employees under temporary contracts are subjected to bad working conditions and have relatively weak wages compared to the holders of permanent contracts (D' Addio and Rosholm, 2005; Fomba Kamga, 2008). On this basis, the holders of a limited time contract are on the secondary segment of the labor market whereas those with a permanent contract are on the primary segment.

Under the efficiency wages framework related to shirking (Shapiro and Stiglitz, 1984), employees under temporary contracts are thus willing to provide less effort than those under permanent contracts. This analysis highlights the interest to study the impact of the contractual statutes of employees on their level of effort.

The present study contributes to the existing literature on several regards. First, it continues the micro-level analysis of temporary contracts initiated by Booth et al. (2002) (Note 1) and pioneers in developing countries, especially in Sub Saharan Africa. Second, beyond the distinction temporary and permanent contract the paper considers the specificities of the Cameroonian labor market by integrating the written or verbal character of the labor contract as well as the affiliation of the employee to social security. Moreover, this study integrates the transition on the labor market and can compare the shirking habits of employees who have been promoted (Note 2) and those employees who have not. On the methodological front, while several papers consider labor contracts as an exogenous variable, we take into account their endogenous character.

The rest of the paper is organized as follows. Section two briefly describes some institutional aspects of the Cameroonian labor market. Section 3 presents the data and specifies the methodology. Section 4 provides the estimation results before some concluding remarks in the last section.

\section{Some institutional aspects}

The 1992 Labor code built on the wind of liberalism which blew in Africa and in Cameroon since 1990. Its ambition was to improve the flexibility of the labor market and thus allow firms to be more competitive. Thus the specified period labor contract which was the exception in the Labor code of 1974 became as legal as employment form 
different from the permanent contract (by duration, degree of attachment to the firm and number of renewals). From this framework, first, the employees working for the firm without being under its administrative responsibility can either be recruited by a drudge or sub-contractor company or temporary work companies. Second, employees working for the firm under its direct responsibility can either be recruited for an unspecified or for a specified period. Apart from the number of hours worked per day and/or week, relationships with the firm differ by the duration, the written nature of labor contract, the possibility of becoming permanent and the affiliation to social security (SS). These characteristics are summarized in table 1.

The intriguing feature in this table is the verbal character of some labor contracts, namely the UPC. Thus, the Labor code 1992 considers that any fixed duration contract that runs out without renewal is regarded as permanent. However, considering a verbal contract as UPC or automatically transforming a specified period contract into an UPC can bring up acute disparities in terms of wages, productivity, effort, etc. To put forward these disparities, the present study regards only duly signed contracts as UPC.

\section{Data and modeling strategies}

Data used in this study were field collected in 2006. The survey covered companies with at least 15 employees and located in the main Cameroon towns, namely Yaoundé and Douala. The method of quotas was used to determine the number of firms and employees to be surveyed in each city and each firm. The companies were selected from the directory of Cameroonian companies available at the National Institute of Statistics (NIS). After data processing, a sample of 65 companies and 1809 employees were retained. The questionnaire presented to the employees concerned socio-demographic indicators, the contractual trajectory of employees, the measurement of effort, etc.

\subsection{Measurement of some key variables}

The literature highlights objective and subjective measurements of effort. Objective measurements of effort have the characteristics of being observable and comparable. The mostly used indicators are absenteeism (Barmby, 2002; Johansson and Palme, 2002; Ichino and Riphahn, 2001; Riphahn and Thalmaier, 2001; Jimeno and Toharia, 1996), the intensity to work (Engellandt and Riphahn, 2005) or unpaid overtime. The main limit of this approach is the lack of the hidden aspects of effort which are important and present in any agency relationship. Moreover, absenteeism can be involuntary due for instance to health problems. In this case, there is no link with effort.

Subjective measurements of effort are neither observed by the employer nor by someone else. The level of effort furnished by the employee is thus auto valued, because observable by the employee himself. These measurements can be captured by asking the employees to evaluate their level of effort on a Likert scale. The limit of an indicator with several levels is the heterogeneity of the evaluation, and employees can under evaluate or over evaluate their own level of effort. The subjective indicator used here results from the answer to the following question: Do you think all your competences are devoted to this company? $1=$ yes, $2=$ no. Among the 1809 employees interviewed, 372 declare shirking whereas 1437 state not to.

The key explanatory variable of this paper is the contractual status of the employee. As state by the Cameroonian labor Code, employees are classified according to two criteria: the written or verbal nature of the labor contract (UPC or SPC); and the affiliation of the employee to social security.

Given the principle of promotion, the contractual choices of employees result from the process illustrated by figure 1 . This process is based on the idea that the employees hired under verbal contracts without SS, written contracts without SS and UPC with SS cannot be promoted. On the other hand, those hired under SPC with SS and verbal contracts with SS can benefit from a promotion. From this process we derive seven (7) possibilities of choice to the employees. Table 2 gives the denomination used in this context for each possibility. The first term of the fifth column indicates the contractual status at the time of recruitment and the second term the contractual status at the time of interview.

Table 3 shows that among the employees who cheat, 28.76\% were recruited under UPC with SS whereas only $22.31 \%$ of the employees still under the most precarious status (verbal without SS) cheat. Employees engaged under SPC with SS and who are still there, account for only $3.76 \%$. The chi square test gives chi $2=43.2709$ with p-value of 0.0000 . These results confirm that the level of effort and the contractual forms are interdependent but there is no information about magnitude and direction of this relationship.

\subsection{Modeling strategy}

Our purpose is to test whether workers with temporary contracts provide more effort than those permanently employed. To ensure that the measured outcomes are not due to composition effects, the model introduces control variables describing the individual worker (age, sex, marital status, education, tenure, etc.), and job (tenure, firm size, industry, occupation). The effort variable has two options: the employee cheats or not. The binary logistic regression model is adapted for this analysis (Note 3).

Previous works on the relation between effort and labor contracts often treat the latter as an exogenous variable (Jimeno and the Cortes, 1996; Engellandt and Riphahn, 2005). However in reality, signing a particular contract during recruitment or when moving from a precarious to permanent situation depends on the characteristics of the employees, the economic conjuncture and the characteristics of the firm (D'Addio and Rosholm, 2005). To solve this insufficiency, it is essential to purge endogeneity from the employees' contractual trajectory. We use two stages 
methodology. It consists in estimating the employees' contractual trajectory on its various determinants and to obtain the predicted probabilities which will be later used in the effort function.

The employees' contractual trajectory is summarized in figure 1. This figure shows that the employees have the choice between seven destinations. This can be captured by a nested logit model (Note 4). The probability of accepting contract $j$ is given by the following expression:

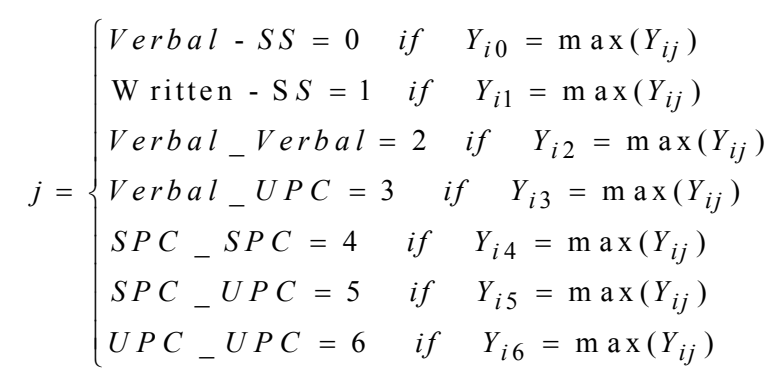

The choices are described by a "random utility model". Let us suppose that the utility drawn by the individual $i$ from choice $j$ is given by:

$$
U_{i j}=Z_{i j}^{\prime} \beta+\varepsilon_{i j}
$$

Where $Z_{i j}^{\prime}, \beta$ and $\varepsilon_{i j}$ are characteristics of workers and firms, parameters to be estimate and error term respectively. This choice is made only when he obtains the maximum utility among the other $J$ utilities. Consequently, the statistical model is described by the probability that the $J$ choice is made, which is:

$$
P_{i j}=\operatorname{Pr} o b\left(U_{i j}>U_{i k} ; \forall k \neq j\right)=\operatorname{Pr} o b\left(Z^{\prime} \beta+\varepsilon>0 \mid Z\right)
$$

Running this model is only possible when the distribution of the random error term is known. For this study, we use the multinomial logit to perform the estimation.

$$
\operatorname{Pr} o b\left(Y_{i}=j\right)=\frac{\exp \left(Z_{i j}^{\prime} \beta\right)}{\sum_{j=0}^{j=6} \exp \left(Z_{i j}^{\prime} \beta\right)}
$$

Where $Y_{i}=j$ indicates that the dependent variable $Y$ for individual $i$ takes the values $j=0,1,2,3,4,5,6$.

Description of variables is given in the annex. Table 4 gives the descriptive statistics of some variables. The executives are among employees who do not cheat. They are followed by the operators, that is, $11.56 \%$ and $18.55 \%$ respectively. Skilled workers and supervisors are represented almost in the same proportions among the employees who cheat, that is, $25.27 \%$ and $24.19 \%$ respectively. Among those who do not cheat, the supervisors and executives are less represented that is, $16.63 \%$ and $6.89 \%$ respectively. This result shows that employees of higher socio professional categories have a relative incentive to effort. This behavior can be explained by the fact that they are generally intended for supervision. In the same order of idea, the employees of the lower categories are strongly represented among those who do not cheat that is, $21.09 \%, 23.59 \%$ and $31.80 \%$ for workers, unskilled workers and skilled workers respectively. Men cheat more than women since $85 \%$ of shirkers are men. Human capital does not act uniformly on the level of effort. Employees having a secondary level of education cheat more than all others.

The food sector is where cheating is low $(11 \%)$. These results can be due to the difficulty in setting standards to control the employees in the chemical sector and a relative facility to do the same in the food sector. In large companies, we note that employees are more inclined to shirk (more than $69 \%$ of workers) contrary to small companies where shirking accounts for only $6 \%$.

\section{Empirical results}

Results are presented in tables 5 and 7. The former gives the marginal effects of the choice of contractual trajectory and the latter the determinants of the level of effort.

\subsection{Contracts}

In table 5 the reference variable is the trajectory verbal - verbal contract, which is supposed to be the most precarious. The model is overall significant as indicated by the $p$-value $=0.0000$. The remaining results are presented in two sequences relating first to the characteristics of the employee and, second to the characteristics of the company.

The results obtained show that the probability of remaining under the written contract without affiliation to social security or following trajectory SPC - SPC decreases with age. Being aged $36-45$ years increases by $14.11 \%$ the probability of following a verbal trajectory - UPC. Moreover, employees aged 26 - 35 years, 36 - 45 years and at least 
46 years, have in terms of relative risk 5 times, 15 times and 6 times respectively more chances than employees of less than 25 years to follow the SPC - UPC trajectory. This analysis shows that insecure and precarious contracts are reserved to young people. To have been under an insecure contract before recruitment increases the probability of being hired under an insecure contract, and decreases the chances of having an UPC. Similarly, to have been under an UPC increases of almost $28 \%$ the probability to sign an UPC when hired in a new company.

Employers avoid holdup problems. This is why they prefer to pay for training of employees under a stable status, especially those recruited under UPC. Also, being a graduate of the general higher education increases by $14.15 \%$ the probability to be hired under UPC. This result shows that the graduates of general higher education having more information on the employment picture on the labor market improve their negotiation capacity and increase their chances to get stable jobs.

Regarding the characteristics of the company, it appears that to be employed in the mechanical sector decreases by $13.78 \%$ the chances to sign an UPC when recruited. However, moving from a verbal contract to an UPC increases them by $10.58 \%$. Similarly, in the food sector, the probability of moving from a verbal contract to an UPC increases by $13.75 \%$. As for the size of the company, we note that the chances of being hired under an UPC decrease in the average sized companies, that is, those with 50 - 100 workers.

As far as the economic environment is concerned, to be hired after 1995 reduces the chances to get a stable job, this shows that the return of economic growth in Cameroon is accompanied by the precariousness of the labor market.

\subsection{Effort}

In table 7, the first two columns represent the determinants of effort when the choice of the contractual trajectory is supposed to be exogenous whereas columns 3 and 4 represent the determinants of effort when the endogeneity of the choice of the contractual trajectory is controlled. Both models are globally significant, but the model including endogeneity behaves better.

The effects of the contractual status on the employees' level of effort have diversified results. Employees under UPC after a verbal contract provide more efforts than employees recruited under UPC. Following this trajectory increases by $56.41 \%$ the probability of not cheating when the endogeneity of the contractual status is taken into account. This result contrasts with Booth et al. (2002) which show that the absenteeism rate (respectively the number of not paid overtime) increases (respectively decreases) for the employees of Italian banks after their probationary period. In the case of Cameroun, we note that the signature of an UPC is not the finality of the employees under verbal contract. Thus if insecure contracts are regarded as a springboard towards the UPC, it is quite obvious that the signature of an UPC is an intermediate objective for the employees recruited under verbal contract.

The fact of not being affiliated to social security encourages the employees to shirk. To be under a verbal contract or written contract without affiliation to social security increases by $6.04 \%$ and $18.85 \%$ respectively the probability of cheating in model 1 . This result shows that for these employees, the signature of an UPC is not a final aim but the wage is more important. As seen in table 6, the groups of employees who have the weakest wages are more willing to cheat.

In like manner, employees under UPC after a SPC or always under UPC value wages more than promotion for shirking. With wages weaker than those employees directly hired under UPC, they prefer to shirk.

The other results show that the probability of shirking increases with the size of the household and the exercise of an auxiliary activity. Adding a person in the household increases by $0.98 \%$ the probability of cheating whereas; the exercise of an auxiliary activity increases by $18.09 \%$ the probability of shirking. This result can be due to the fact that increasing the size of the household very often results in increasing family responsibilities (marriage, number of children in charge of, etc) which reduce the attachment of the worker to his main activity. Moreover, this increase in responsibility is accompanied by requirements in terms of income for family subsistence. The worker can thus be obliged to supplement the income from the main activity by the income from the auxiliary activity. In addition, the probability of cheating increases with the job located in Douala, the food and plastic sectors, the graduation from the technical higher education.

A contrario, the probability of not cheating increases with the age of worker and size of the company. Being at least 46 years old increases by $9.96 \%$ the probability of not cheating, which means that seniors are somehow attached to their main activity. In small or medium sized companies, supervision can be rather easy and justifies that their employees cannot cheat.

\section{Conclusion}

The main objective of this paper was to determine the effects of labor contracts on Cameroonian employee shirking behavior. Beyond the distinction permanent versus temporary, this paper has taken into consideration the peculiarities of the Cameroonian labor market: the verbal nature of some labor contracts and affiliation to social security. Moreover, this work integrates the transition or promotion from precarious position to the permanent contract. This made it possible by assembling the employees in seven groups. Shirking is measured by a subjective variable showing that labor contract is an agency relation. Our work was partly based on the fact that employees under temporary contracts are more likely not to cheat in order to get to the permanent status and on the other hand, 
that employees under temporary contracts mostly find themselves on the secondary segment and under the hypotheses of efficiency wage theories are more likely to shirk compared to those under permanent contracts.

The results obtained show that employees under UPC after a verbal contract are more likely to make more efforts than those under UPC since their recruitment. Following this contractual trajectory increases about $56.41 \%$ the probability of not shirking. A contrario, the fact of being under a SPC since recruitment, increases by $60.86 \%$ the probability to shirk. In the same way, having no affiliation to social security increases the probability to shirk. These results show that the expected benefits from using temporary employees (wage costs) can be cancelled by shirking.

\section{References}

Barmby, T.; Marco, A.; Ercolani, G. \& Treble, J.G. (2002). Sickness absence: an international comparison. Economic Journal, 101, 315-331.

Bentolila, S. \& Bertola, G. (1990). Firing costs and labor demand: how bad is eurosclerosis? Review of Economic Studies, 57, 381-402.

Bertola, G. (1990). Job security, employment and wages. European Economic Review, 34, 851-886.

Blanchard, O. \& Landier, A. (2002). The perverse effects of partial labour market reform: fixed-term contracts in France. Economic Journal, 112, 214-244.

Booth, A.; Francesconi, M. \& Frank, J. (2002). Temporary jobs: stepping stones or dead ends? Economic Journal Features, Symposium on Temporary Work, 189-213.

Cahuc, P. \& Postel-Vinay, F. (2002). Temporary jobs, employment protection and labor market performance. Labour Economics, 9, 63-91.

D'Addio, A.C. \& Rosholm, M. (2005). Exits from temporary jobs in Europe: a competing risks analysis. Labour Economics, 12, 449-468.

Décret $n^{\circ}$ 93/577/PM du 15 juillet 1993 fixant les conditions d'emploi des travailleurs temporaires, occasionnels ou saisonniers.

Engellandt, A. \& Riphahn, R.T. (2005). Temporary contracts and employee effort. Labour Economic, 12, 281-299.

Fomba Kamga B. (2008). Contrat de Travail et Fonctionnement du Marché du Travail au Cameroun. Thèse de Doctorat, Ph.D en Sciences Economiques non publiée, Université de Yaoundé II-Soa.

Güell M. \& Petrongolo. (2007). How Binding are Legal Limits? Transition from Temporary to Permanent Work in Spain. Labour Economics, Vol. 14, 153 - 183.

Ichino, A. \& Riphahn, R.T. (2001). The effect of employment protection on worker effort: a comparison of Absenteeism during and after Probation. IZA Discussion Paper, $\mathrm{N}^{\circ} 385,1-18$.

Institut National de la Statistique (2005). Enquête sur l'emploi et le secteur Informel au Cameroun, premiers indicateurs phase1, Mimeo.

Jimeno, J.F. \& Toharia, L. (1993). The effects of fixed-term employment on wages: theory and evidence from Spain. Investigaciones Economicas, 17, 475-494.

Jimeno, J.F. \& Toharia, L. (1996). Effort, absenteeism and fixed-term employment contracts. Revista de Economia Aplicada, 13, 105-119.

Johannson, P. \& Palme, M. (2002). Assessing the effect of public policy on worker absenteeism. Journal of Human Resources, 37, 381-409.

Loi n 92/007 du 14 Août 1992 portant Code du Travail du Cameroun.

Riphahn, R.T. \& Thalmaier, A. (2001). Behavioral effects of probation periods: an analysis of worker absenteeism. Jahrbücher für Nationalökonomie und Statistik, 221, 179-201.

Shapiro, C. \& Stiglitz, J. (1984). Equilibrium unemployment as a discipline device. American Economic Review, June.

Notes

Note1: Booth and al (2002) made it possible to show that temporary contracts lead to permanent contracts. In the case of Great Britain, they confirm that a great proportion of employees under temporary contracts move to permanent contracts with wage increase and advantages linked to the job.

Note 2: In this framework, job promotion is moving from a precarious contract to a permanent one.

Note 3: This study prefers the logistic model because of its flexibility in manipulations and the calculation of odds ratios; indicators which improve the interpretation of the results.

Note 4: Its estimation requires a particular treatment but, it allows deducing probabilities for each level and not probabilities for each choice. However from the decision tree of figure 1, only the probabilities of the last level alternatives can be given. Moreover, the implementation of such a model requires that the characteristics of the 
various choices be known. In reality, these characteristics are non-existent and this is why this militates in favor of the simple multinomial logit model.

Annex: Description of variables

\begin{tabular}{|c|c|}
\hline Variables & Definitions \\
\hline Effort & (2) Two modalities Variable coded as follows: $0=$ cheats, $1=$ does not cheat. \\
\hline Labor contrat & $\begin{array}{l}\text { (4) Four modalities Variable coded as follows: } 0=\text { precarious contracts (informal and SPC); } 1=\mathrm{UPC} \text { after an } \\
\text { informal contract; } 2=\mathrm{UPC} \text { after a SPC; } 3=\mathrm{UPC} \text { since recruitment. Each of these modalities will sometimes be } \\
\text { transformed into variable. }\end{array}$ \\
\hline Age & $\begin{array}{l}\text { The age in years in measured by four (4) qualitative variables } \\
\text { age } \leq 25 ; \text { age } \in[26,35] ; \text { age } \in[36,45] ; \text { age } \geq 46\end{array}$ \\
\hline Education & $\begin{array}{l}\text { The type and level of education are measured by five (5) qualitative variables which are: at most primary level, } \\
\text { general secondary, technical secondary, general higher et technical higher. }\end{array}$ \\
\hline Training & Is measured by two qualitative variables which are : training and no training \\
\hline Seniority & Number of years spent in the present firm, measured in months. \\
\hline $\begin{array}{l}\text { Socio professional } \\
\text { Categories }\end{array}$ & Five categories are selected: workers, unskilled workers, skilled workers, supervisory staff, and manager staff. \\
\hline Labor status before & It has four (4) qualitative variables: unemployed, verbal contract, SPC and UPC. \\
\hline $\begin{array}{l}\text { Means used for } \\
\text { hiring }\end{array}$ & There were three qualitative variables: social network, demand and company. \\
\hline \multicolumn{2}{|c|}{ Characteristics of the firm } \\
\hline Location of the firm & The location of firm is measured by two qualitative variables: Douala and Yaoundé. \\
\hline Size of the firm & $\begin{array}{l}\text { The size in number of employees is measured by four (4) qualitative variables that is : size }<25 \text {, size } \in[25,50[\text {, } \\
\text { size } \in[50,100[\text { and size } \geq 100\end{array}$ \\
\hline Sector of activity & $\begin{array}{l}\text { Qualitative variable represented by four (4) modalities transformed into dummy variables which are: chemical } \\
\text { sector, food sector, plastic and paper sector, mechanic and wood sector. }\end{array}$ \\
\hline
\end{tabular}

N.B. Workers is the low level of socio professional categories.

Table 1. Characteristics of labor contracts.

\begin{tabular}{|c|c|c|c|c|c|c|}
\hline Contracts & Duration & Renewal & Max duration & Written & Towards UPC & SS \\
\hline UPC & Undetermined & & & Optional & Yes \\
\hline Trial & Variable & 1 & Variable & Written & Yes & Yes \\
\hline SPC & 24 months & 1 & 48 months & Written & Yes & Yes \\
\hline Temporary C & 3 months & 1 & 6 months & Optional & Yes & Yes \\
\hline Occasional C & 15 days & 1 & 1 month & Optional & Yes & Yes \\
\hline Seasonal C & 6 months & Several & - & Optional & Yes & Yes \\
\hline Apprentice & 48 months & - & 48 months & Written & Yes & Yes \\
\hline
\end{tabular}

The term of a trial-basis contract varies with the socio-professional category of the employee. It is 15 days for categories 1 and 2, 1 month

for categories 3 and 4,2 months for categories 5 and 6,3 months for categories 7,8 and 9 and 4 months for categories 10,11 and 12. It is sufficient to multiply these durations by 2 to obtain the maximum durations. As for the seasonal contracts, they last 6 months duration per annum with the same employer and can thus be repeated each year.

Source: From: Labor Code of 1992, decree $\mathrm{N}^{\circ}$ 93/577/PM of July 15, 1993 and the decree n 091/DF/287 of July 30, 1969.

Table 2. Denomination of different contractual trajectories

\begin{tabular}{|l|l|l|l|l|l|}
\hline Number & Hiring contract & Contract at interview & Promotion & Denomination & Workers \\
\hline 1 & Verbal without SS & Verbal without SS & No & Verbal - SS & 424 \\
\hline 2 & Written without SS & Written without SS & No & Written - SS & 121 \\
\hline 3 & Verbal with SS & Verbal with SS & No & Verbal - Verbal & 224 \\
\hline 4 & Verbal with SS & UPC with SS & Yes & Verbal - UPC & 280 \\
\hline 5 & SPC with SS & SPC with SS & No & SPC - SPC & 66 \\
\hline 6 & SPC with SS & UPC with SS & Yes & SPC - UPC & 148 \\
\hline 7 & UPC with SS & UPC with SS & No & UPC - UPC & 546 \\
\hline
\end{tabular}


Table 3. Interdependence between contractual choice and the level of effort.

\begin{tabular}{|l|c|c|c|c|c|c|c|c|}
\hline Effort & \multicolumn{7}{|c|}{ Contractual choice } & \\
\hline \multicolumn{1}{|c|}{ Effort } & Verbal - SS & Written - SS & Verbal -Verbal & Verbal -UPC & SPC - SPC & SPC - UPC & UPC - UPC & Total \\
\hline Shirking & $\mathbf{8 3}$ & $\mathbf{4 5}$ & $\mathbf{4 9}$ & $\mathbf{3 1}$ & $\mathbf{1 4}$ & $\mathbf{4 3}$ & $\mathbf{1 0 7}$ & $\mathbf{3 7 2}$ \\
& 22.31 & 12.10 & 13.17 & 8.33 & 3.76 & 11.56 & 28.76 & 100.00 \\
& 19.58 & 37.19 & 21.88 & 11.07 & 21.21 & 29.05 & 19.60 & 20.56 \\
\hline No shirking & $\mathbf{3 4 1}$ & $\mathbf{7 6}$ & $\mathbf{1 7 5}$ & $\mathbf{2 4 9}$ & $\mathbf{5 2}$ & $\mathbf{1 0 5}$ & $\mathbf{4 3 9}$ & $\mathbf{1 4 3 7}$ \\
& 23.73 & 5.29 & 12.18 & 17.33 & 3.62 & 7.31 & 30.55 & 100.00 \\
& 80.42 & 62.81 & 78.13 & 88.93 & 78.79 & 70.95 & 80.40 & 79.44 \\
\hline Total & $\mathbf{4 2 4}$ & $\mathbf{1 2 1}$ & $\mathbf{2 2 4}$ & $\mathbf{2 8 0}$ & $\mathbf{6 6}$ & $\mathbf{1 4 8}$ & $\mathbf{5 4 6}$ & $\mathbf{1 8 0 9}$ \\
& 23.44 & 6.69 & 12.38 & 15.48 & 3.65 & 8.18 & 30.18 & 100.00 \\
& 100 & 100,00 & 100.00 & 100.00 & 100.00 & 100.00 & 100.00 & 100.00 \\
\hline
\end{tabular}

Source: Survey. The figures in italic are the proportions in column and the last line of each box is the proportion on line

Table 4. Selected sample characteristics by shirking status.

\begin{tabular}{|c|c|c|}
\hline Variables & Shirking & No shirking \\
\hline Effectifs & $20.56 \%$ & $79.44 \%$ \\
\hline Age $<=25$ & $9.14(0.0150)$ & $8.70(0.0074)$ \\
\hline Age $26-35$ & $52.69(0.0259)$ & $48.09(0.0132)$ \\
\hline Age $36-45$ & $27.15(0.0231)$ & $28.67(0.0119)$ \\
\hline Age $>46$ & $11.02(0.0163)$ & $14.54(0.0093)$ \\
\hline Worker (operation) & $18.55(0.0202)$ & $21.09(0.0108)$ \\
\hline Unskilled Worker & $20.43(0.0209)$ & $23.59(0.0112)$ \\
\hline Skilled worker & $25.27(0.0226)$ & $31.80(0.0123)$ \\
\hline Supervisory staff & $24.19(0.0222)$ & $16.63(0.0098)$ \\
\hline Management staff & $11.56(0.0166)$ & $6.89(0.0067)$ \\
\hline Single & $48.39(0.0259)$ & $44.47(0.0131)$ \\
\hline Married & $51.61(0.0259)$ & $55.53(0.0131)$ \\
\hline Male & $83.60(0.0192)$ & $\begin{array}{ll}83.79 & (0.0097)\end{array}$ \\
\hline Female & $16.40(0.0192)$ & $16.21(0.0097)$ \\
\hline Primary & $18.28(0.0201)$ & $25.05(0.0114)$ \\
\hline Second $\mathrm{T}$ & $26.34(0.0229)$ & $27.35(0.0118)$ \\
\hline Second G & $26.34(0.0229)$ & $31.18(0.0122)$ \\
\hline High tech & $17.74(0.0198)$ & $8.07(0.0072)$ \\
\hline High. Gene. & $11.29(0.0164)$ & $8.35(0.0073)$ \\
\hline Tenure & $84.4328(4.4632)$ & $94.8149(2.3816)$ \\
\hline Experience & $111.0806(5.1197)$ & $118.0619(2.7260)$ \\
\hline No training & $73.38(0.0229)$ & $72.79(0.0117)$ \\
\hline Training & $26.61(0.0229)$ & $27.21(0.0117)$ \\
\hline Demand and test & $67.51(0.0248)$ & $61.33(0.0130)$ \\
\hline Social capital & $31.37(0.0245)$ & $37.66(0.0129)$ \\
\hline Company (FNE) & $11.20(0.0056)$ & $1.00(0.0026)$ \\
\hline Douala & $95.95(0.0102)$ & $92.00(0.0072)$ \\
\hline Yaoundé & $4.05(0.0102)$ & $8.00(0.0072)$ \\
\hline Chemical & $40.32(0.0255)$ & $35.98(0.0127)$ \\
\hline Food & $11.02(0.0163)$ & $21.16(0.0108)$ \\
\hline Plastic & $25.54(0.0226)$ & $19.76(0.0105)$ \\
\hline Mechanic & $23.12(0.0219)$ & $23.10(0.0111)$ \\
\hline Size $<25$ & $5.65(0.0120)$ & $6.12(0.0063)$ \\
\hline$[25-50[$ & $16.13(0.0191)$ & $19.00(0.0104)$ \\
\hline$[50-100[$ & $9.14(0.0150)$ & $14.34(0.0092)$ \\
\hline$\geq 100$ & $69.09(0.0240)$ & $60.54(0.0129)$ \\
\hline
\end{tabular}

Source: Survey. The values in parentheses are standard deviations. 
Table 5.Estimation results of contract status (marginal effects)

\begin{tabular}{|c|c|c|c|c|c|c|}
\hline & Without SS & & & With SS & & \\
\hline & Written & Verbal- Verbal & Verbal - UPC & SPC - SPC & SPC - UPC & UPC - UPC \\
\hline Age & & & & & & \\
\hline Age26-35 & $0.0557(-2.35)^{* *}$ & $-0.0497(-1.25)$ & $0.0845(1.42)$ & $-0.0179(-1.10)$ & $0.0822(1.65)^{*}$ & $0.0494(0.71)$ \\
\hline Age-46 & $-0.0560(-2.45)^{* *}$ & $0.0480(0.65)$ & $0.1179(1.18)$ & $-0.0358(-3.18)^{* * *}$ & $0.0845(0.91)$ & $-0.0509(-0.58)$ \\
\hline Male & $-0.0282(-1.21)$ & $0.0349(1.22)$ & $0.0214(0.72)$ & $0.0065(0.58)$ & $-0.0001(-0.01)$ & $-0.0108(-0.28)$ \\
\hline Married & $0.0193(1.19)$ & $-0.0671(-2.65)^{* * *}$ & $0.0675(2.86)^{* * *}$ & $0.0006(0.06)$ & $0.0132(1.01)$ & $0.0408(1.25)$ \\
\hline Second T & $0.0034(0.15)$ & $0.0039(0.13)$ & $-0.0235(-0.80)$ & $-0.0026(-0.17)$ & $0.0170(0.78)$ & $-0.0167(-0.39)$ \\
\hline Second $\mathrm{G}$ & $0.0131(0.57)$ & $-0.0382(-1.43)$ & $-0.0120(-0.41)$ & $0.0025(0.15)$ & $0.0266(1.15)$ & $0.0040(0.09)$ \\
\hline High tech & $0.0002(0.01)$ & $-0.0215(-0.47)$ & $-0.0286(-0.68)$ & $-0.0003(-0.02)$ & $0.0085(0.28)$ & 0.0954 (1.49) \\
\hline High. Gene. & $0.0059(0.17)$ & $-0.0422(-0.95)$ & $-0.0335(-0.74)$ & $-0.0141(-0.88)$ & $0.0216(0.62)$ & $0.1415(2.08)^{* *}$ \\
\hline Contract before & & & & & & \\
\hline Verbal - SS & $0.0744(2.26)^{* *}$ & $0.0096(0.29)$ & $-0.0854(-3.44)^{* * *}$ & $-0.0045(-0.35)$ & $-0.0046(-0.27)$ & $-0.0446(-1.02)$ \\
\hline Trainers & $-0.0014(-0.09)$ & $-0.0477(-2.05)^{* *}$ & $0.0857(3.28)^{* * *}$ & $-0.0026(-0.27)$ & $0.0285(1.96)^{* *}$ & $0.0594(1.88)^{*}$ \\
\hline Profession & & & & & & \\
\hline unskilled worker & $-0.0441(-2.78)^{* * *}$ & $-0.0716(-2.83)^{* * *}$ & $0.0265(0.67)$ & $-0.0091(-0.46)$ & $0.1250(2.07)$ & $0.0958(1.53)$ \\
\hline skilled worker & $-0.0663(-3.92)^{* * *}$ & $-0.1174(-4.72)^{* * *}$ & $0.0256(0.69)$ & $0.0508(1.74)^{*}$ & $0.1340(2.52)$ & $0.1673(2.81)^{* * *}$ \\
\hline supervisory staff & $-0.0730(-5.09)^{* * *}$ & $-0.1333(-5.85)^{* * *}$ & $-0.0157(-0.40)$ & $0.0361(1.08)$ & $0.0894(1.56)$ & $0.2938(4.20)^{* * *}$ \\
\hline management staff & $-0.0643(-4.59)^{* * *}$ & $-0.1696(-10.06)^{* * *}$ & $-0.1045(-3.01)^{* * *}$ & $0.0608(1.06)$ & $0.0928(1.18)$ & $0.3394(3.67)^{* * *}$ \\
\hline Trade union & $-0.0554(-3.64)^{* * *}$ & $0.0101(0.47)$ & $0.1080(4.72)^{* * *}$ & $-0.0285(-2.91)^{* * *}$ & $0.0187(1.50)$ & $0.1226(4.15)^{* * *}$ \\
\hline Company & $0.0596(1.27)$ & $-0.0229(-0.43)$ & $-0.0369(-0.78)$ & $-0.0085(-0.48)$ & $0.0413(1.19)$ & $-0.1498(-2.78)^{* * *}$ \\
\hline Social capital & $-0.0017(-0.11)$ & $0.0269(1.15)$ & $0.0019(0.09)$ & $-0.0063(-0.60)$ & $-0.0284(-2.21)$ & $-0.0379(-1.22)$ \\
\hline Douala & $0.0284(1.21)$ & $-0.2121(-3.31)^{* * *}$ & $0.1746(9.24)^{* * *}$ & $-0.0023(-0.12)$ & $0.0599(4.32)$ & $-0.0027(-0.04)$ \\
\hline Sector of activity & & & & & & \\
\hline Growth & & & & & & \\
\hline Before 1987 & $0.1379(0.84)$ & $0.0080(0.11)$ & $-0.1177(-3.47)^{* * *}$ & $-0.0242(-1.79)^{*}$ & $-0.0255(-1.07)$ & $0.0209(0.21)$ \\
\hline After 1995 & $0.0819(2.57)$ & $0.0509(1.17)$ & $-0.0215(-0.51)$ & $-0.0404(-1.31)$ & $0.0104(0.49)$ & $-0.1423(-2.23)^{* *}$ \\
\hline Probability & 0.0780 & 0.1592 & 0.1724 & 0.0362 & 0.0667 & 0.3426 \\
\hline
\end{tabular}

Note: ${ }^{* *}(* *) *$ statistically significant at $1 \%(5 \%)$ and $10 \%$.

Table 6. Distribution of wages (in thousands of CFA)

\begin{tabular}{|l|l|l|l|l|l|}
\hline & Wage & Standard deviation & Workers & Rank & Shirking \\
\hline Verbal - SS & 77.730 & 60.618 & 424 & 1 & YES \\
\hline Written - SS & 144.267 & 125.708 & 121 & 3 & YES \\
\hline Verbal-Verbal & 121.51 & 77.535 & 224 & 2 & YES \\
\hline Verbal - UPC & 179.623 & 116.726 & 280 & 4 & NO \\
\hline SPC - SPC & 283.569 & 122.748 & 66 & 6 & YES \\
\hline SPC - UPC & 223.380 & 162.192 & 148 & 5 & YES \\
\hline UPC - UPC & 294.926 & $269 . .114$ & 546 & 7 & - \\
\hline Total & 184.859 & 190.664 & 1809 & & \\
\hline
\end{tabular}

Source: Survey 
Table 7. Estimate results of the effort function.

\begin{tabular}{|c|c|c|c|c|}
\hline & Coefficients & Marginal Effets & Coefficients & Marginal effect \\
\hline \multicolumn{5}{|l|}{ Age } \\
\hline Age26-35 & $0.0175(0.08)$ & $0.0025(0.08)$ & $-0.2846(-1.07)$ & $-0.0418(-1.07)$ \\
\hline Age36-45 & $0.3674(1.37)$ & $0.0510(1.44)$ & $-0.1990(-0.56)$ & $-0.0300(-0.55)$ \\
\hline Age-46 & $0.8310(2.22)^{* *}$ & $0.0996(2.77)^{* * *}$ & $0.4347(1.01)$ & $0.0575(1.12)$ \\
\hline Male & $-0.2515(-1.42)$ & $-0.0348(-1.50)$ & $-0.2125(-1.16)$ & $-0.0297(-1.22)$ \\
\hline Household size & $-0.0669(-2.75)^{* * *}$ & $-0.0097(-2.75)^{* * *}$ & $-0.0667(-2.67)^{* * *}$ & $-0.0098(-2.68)^{* * *}$ \\
\hline Secondary job & $-0.8990(-5.22)^{* * *}$ & $-0.1608(-4.49)^{* * *}$ & $-0.9912(-5.77)^{* * *}$ & $-0.1809(-4.94)^{* * *}$ \\
\hline \multicolumn{5}{|l|}{ Education } \\
\hline Second $\mathrm{T}$ & $-0.0074(-0.04)$ & $0.0010(-0.04)$ & $-0.0419(-0.21)$ & $-0.0381(-1.20)$ \\
\hline Second G & $-0.1959(-1.01)$ & $-0.0294(-0.98)$ & $-0.2503(-1.24)$ & $-0.0587(-1.05)$ \\
\hline High tech & $-0.9231(-3.47)^{* * *}$ & $-0.1670(-2.96)^{* * *}$ & $-0.7616(-2.77)^{* * *}$ & $-0.1338(-2.40)^{* *}$ \\
\hline High. Gene. & $-0.3931(-1.34)$ & $-0.0635(-1.22)$ & $-0.3643(-1.14)$ & $-0.0587(-1.05)$ \\
\hline Trainers & $0.0687(0.45)$ & $0.0099(0.46)$ & $-0.1295(-0.73)$ & $-0.0193(-0.72)$ \\
\hline Tenure & $0.0023(0.17)$ & $0.0003(0.17)$ & $0.0157(1.06)$ & $0.0023(1.06)$ \\
\hline \multicolumn{5}{|l|}{ Profession } \\
\hline Unskilled Worker & $-0.0515(0.25)$ & $-0.0075(-0.25)$ & $-0.1839(-0.69)$ & $-0.0278(-0.67)$ \\
\hline Skilled worker & $-0.1050(-0.48)$ & $-0.0155(-0.47)$ & $0.0069(0.02)$ & $0.0010(0.02)$ \\
\hline Supervisory staff & $-0.5297(-2.10)^{* *}$ & $-0.0860(-1.91)^{*}$ & $-0.2252(-0.49)$ & $-0.0346(-0.47)$ \\
\hline Management staff & $-0.6300(-1.92)^{*}$ & $-0.1080(-1.68)^{*}$ & $-0.0427(-0.07)$ & $-0.0063(-0.07)$ \\
\hline Trade union & $0.2057(1.41)$ & $0.0297(1.43)$ & $-0.1657(-0.74)$ & $-0.0245(-0.73)$ \\
\hline Company & $0.2394(0.81)$ & $0.0325(0.87)$ & $0.1333(-0.74)$ & $0.0188(0.42)$ \\
\hline Social capital & $0.1917(1.33)$ & $0.0275(1.36)$ & $0.1715(1.11)$ & $0.0247(1.13)$ \\
\hline Douala & $-0.8403(-2.58)^{* * *}$ & $-0.0966(-3.44)^{* * *}$ & $-1.4473(-3.70)^{* * *}$ & $-0.1408(-6.21)^{* * *}$ \\
\hline \multicolumn{5}{|l|}{ Sector of activity } \\
\hline Food & $0.5073(2.37)^{* *}$ & $0.0669(2.66)^{* * *}$ & $0.1150(0.46)$ & $0.0165(0.47)$ \\
\hline Plastic and paper & $-0.3959(-2.22)^{* *}$ & $-0.0622(-2.08)^{* *}$ & $-0.6494(-3.04)^{* * *}$ & $-0.1070(-2.76)^{* * *}$ \\
\hline Mechanic & $0.2217(1.26)$ & $0.0311(1.31)$ & $-0.0662(-0.32)$ & $-0.0098(-0.32)$ \\
\hline \multicolumn{5}{|l|}{ Firm size } \\
\hline$[25-50[$ & $0.4642(1.49)$ & $0.0616(1.65)^{*}$ & $0.5014(1.53)$ & $0.0664(1.71)^{*}$ \\
\hline$[50-100[$ & $0.6196(1.88)^{*}$ & $0.0779(2.22)^{* *}$ & $0.6913(1.90)^{*}$ & $0.0858(2.29)^{* *}$ \\
\hline$\geq 100$ & $-0.0699(-0.25)$ & $-0.0101(-0.25)$ & $-0.0640(-0.20)$ & $-0.0093(-0.20)$ \\
\hline \multicolumn{5}{|l|}{ Contractual status } \\
\hline Verbal-SS & $-0.3872(-1.78)^{*}$ & $-0.0604(1.68)^{*}$ & $0.5341(0.54)$ & $0.0784(0.54)$ \\
\hline Written - SS & $-1.0087(-4.13)^{* * *}$ & $-0.1885(-3.47)^{* * *}$ & $-0.8144(-0.52)$ & $-0.1195(-0.52)$ \\
\hline Verbal - Verbal & $-0.4457(-2.02)^{* *}$ & $-0.0723(-1.84)^{*}$ & $-0.1238(-0.09)$ & $-0.0181(-0.09)$ \\
\hline Verbal - UPC & $0.4485(1.92)^{*}$ & $0.0592(2.16)^{* *}$ & $3.8423(3.07)^{* * *}$ & $0.5641(3.10)^{* * *}$ \\
\hline $\mathrm{SPC}-\mathrm{SPC}$ & $-0.0962(-0.28)$ & $-0.0144(-0.27)$ & $-4.1455(-1.63)^{*}$ & $-0.6086(-1.63)^{*}$ \\
\hline $\mathrm{UPC}-\mathrm{UPC}$ & $-0.4957(-2.14)^{* *}$ & $-0.0823(-1.92)^{*}$ & $1.8586(1.20)$ & $0.2729(1.20)$ \\
\hline Constant & $2.8524(5.14)^{* * *}$ & & $3.6327(5.63)^{* * *}$ & \\
\hline
\end{tabular}

Note: Number of observation $=1809$. Log likelihood $=-832.0893(-836.1936)$; LR chi2 $=174.20$ (165.99). Prob $>$ chi2 $=0.0000$. The values in brackets are $\mathrm{t}$ of student. $* * *(* *) *$ statistically significant at $1 \%(5 \%)$ and $10 \%$.

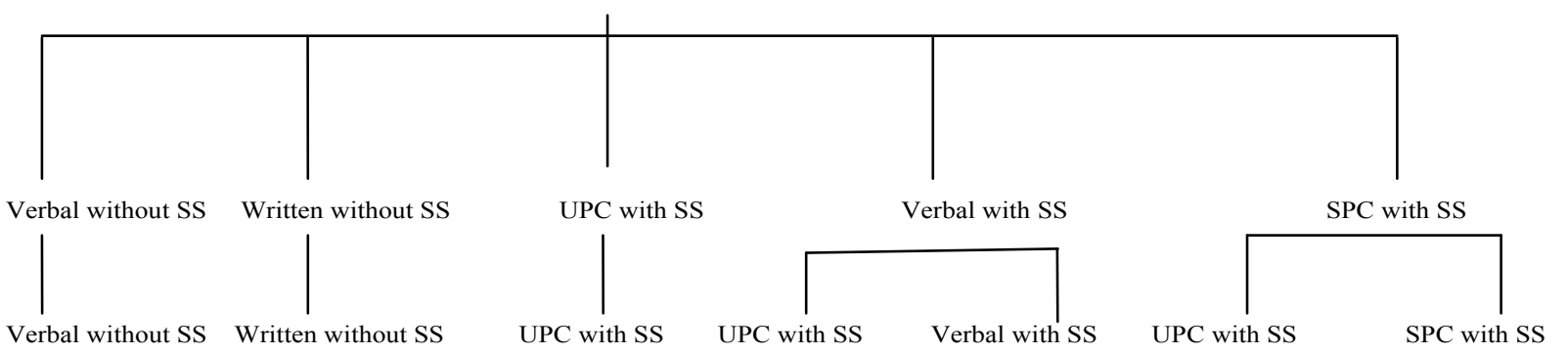

Source: Survey

Figure 1. Decision tree for a contractual choice 